\title{
Analisa Bilirubin Total Penderita Tuberculosis Paru Setelah 5 Bulan Mengkonsumsi Obat Anti Tuberkulosis (OAT)
}

\author{
Tiara Rajagukguk,M.KM \\ Email:tiararajagukguk29@gmail.com brahmananetti@gmail.com \\ Universitas Sari Mutiara Indonesia
}

\begin{abstract}
ABSTRAK
Tuberkulosis (TB) adalah penyakit menular langsung yang disebabkan oleh kuman TB yaitu Mycobacterium tuberculosis.Penderita TB paru dengan hasil pemeriksaan BTA positif merupakan penularan yang paling utama, oleh karena itu diperlukan pengobatan menggunakan Obat Anti Tuberkulosis (OAT). Penelitian ini dilakukan di Rumah Sakit Khusus Paru Medan pada bulan Februari - Juli 2018 dengan menggunakan metode penelitian deskriptif crossectional. Hasil penelitian dari 20 sampel yaitu 2 sampel meningkat $(10 \%)$ dan 18 sampel normal (90 \%). Penyebab terjadinya kenaikan kadar bilirubin total yaitu karena penderita mengkonsumsi OAT secara terus menerus tanpa disertai pola hidup sehat.
\end{abstract}

\section{Kata Kunci : Tuberkulosis, OAT, Bilirubin Total}

\section{ABSTRACT}

Tuberculosis $(T B)$ is a contagious directly disease caused by the TB germ, named Mycobacterium tuberculosis. Patients with pulmonary tuberculosis with the result of positive BTA examination is the most important transmission, therefore the treatment required using Anti-Tuberculosis (OAT). This research was conducted at Pulmonary Specialty Hospital Medan in Jebruari - July 2018 by using descriptive crossectional research method. The results of the study were 20 samples, 2 samples increased (10\%) and 18 normal samples (90\%). The cause of the increase in total bilirubin levels is because the patient consumes OAT continuously without a healthy lifestyle.

\section{Keywords: Tuberculosis, OAT, Total Bilirubin}

\section{PENDAHULUAN}

Tuberkulosis (TB) adalah penyakit menular langsung yang disebabkan oleh kuman TB yaitu Mycobacterium tuberculosis. TB paru tergolong penyakit airborne infection, yang dapat masuk ke dalam tubuh manusia melalui udara pernapasan ke dalam paru-paru kemudian menyebar dari paru-paru ke bagian tubuh lainnya melalui sistem peredaran darah, sistem saluran limfe, melalui bronkus atau penyebaran langsung ke bagian tubuh lainnya (Faisalado dan Triwibowo, 2013).

Berdasarkan data di Rumah Sakit Khusus Paru Medan didapat rata-rata pasien positif TB sebanyak 80 orang. Penderita TB paru dengan hasil pemeriksaan BTA positif 
Journal of Healthcare Technology and Medicine Vol. 5 No. 2 Oktober 2019

Universitas Ubudiyah Indonesia

e-ISSN : 2615-109X

(+) merupakan penularan yang paling utama. Pada saat batuk atau bersin, penderita dapat menyebarkan kuman ke udara dalam bentuk percikan dahak.Percikan dahak yang mengandung kuman dapat bertahan di udara pada suhu kamar selama beberapa jam. TB dapat menyebabkan kematian apabila tidak diobati, 50\% dari pasien TB akan meninggal setelah 5 tahun. Setiap tahunnya seorang yang terdiagnosa TB positif, dapat menularkan kepada 10-15 orang lain, oleh karena itu diperlukan pengobatan Obat Anti Tuberkulosis (OAT), seperti Isoniazid (H), Etambutol (E), Pirazinamid (Z), Rifampicin (R), dan Steptomisin (S) yang diberikan selama 6 bulan (Tabrani Rab, 2010).

Bilirubin di metabolisme oleh hati dan dieksresikan kedalam empedu. Metabolisme bilirubin dimulai oleh penghancuran eritrosit setelah usia 120 hari oleh sistem retikuloendotel menjadi heme dan globin. Akumulasi bilirubin berlebihan di kulit, sklera dan membran mukosa dapat menyebabkan warna kuning yang disebut ikterus. Ikterus atau Hiperbilirubinemia adalah peningkatan kadar bilirubin yang melebihi batas normal (E.N Kosasih dan E.S Kosasih, 2013).

Obat-obat yang dapat meningkatkan kadar bilirubin yaitu obat yang bersifat hepatotoksik (primakuin, sulfa, streptomisin, rifampisin, teofilin, asam askorbat). Peningkatan kadar bilirubin terkonjugasi lebih sering terjadi akibat peningkatan pemecahan eritrosit, sedangkan peningkatan bilirubin tidak terkonjugasi lebih diakibatkan oleh gangguan fungsi hati (Samsu Rian, 2010).

Tuberkulosis (TB) Paru adalah penyakit infeksi yang disebabkan oleh kuman Mycobacterium tuberculosis yang menyerang paru-paru dan bronkus. TB paru tergolong penyakit airborne infection, yang dapat masuk ke dalam tubuh manusia melalui udara pernapasan ke dalam paru paru kemudian menyebar dari paru-paru ke bagian tubuh lainnya melalui sistem peredaran darah, sistem saluran limfe, melaui bronkus atau penyebaran langsung ke bagian tubuh lainnya (Faisalado dan Triwibowo, 2013).

Pengobatan yang digunakan pada penyakit TB adalah penggunaan Obat Anti Tuberkulosis (OAT) obat yang paling umum atau sering digunakan adalah Isoniazid, Etambutol, Rifampisin, Pirazinamid, dan Steptomisin, semua jenis obat ini termasuk dalam golongan obat primer. Tidak hanya itu obat lain yang pernah digunakan adalah Natrium Para Amino Salisilat, Kepreomisin, Sikloserin, Etionamid, Kanamisin, Rifapentin, dan Rifabutin.Natrium Para Amino Salisilat, Kapreomisin, Sikloserin, dan 
Journal of Healthcare Technology and Medicine Vol. 5 No. 2 Oktober 2019

Universitas Ubudiyah Indonesia

e-ISSN : 2615-109X

Etionamid pada dasarnya menyebabkan efek toksik dan dipakai jika obat primer sudah resisten (Samsu Rian, 2013).

Bilirubin adalah pigmen kuning yang berasal dari perombakan heme dari hemoglobin dalam proses pemecahan eritrosit oleh sel retikuloendotel. Di samping itu sekitar $20 \%$ bilirubin berasal dari perombakan zat-zat lain. Sel retikuloendotel membuat bilirubin tidak larut dalam air, bilirubin yang disekresikan dalam darah harus diikatkan albumin untuk diangkut dalam plasma menuju hati.Di dalam hati, hepatosit melepaskan ikatan dan mengkonjugasinya dengan asam glukoronat sehingga bersifat larut air, sehingga disebut bilirubin direk atau glukoroniltransferase, selain dalam bentuk diglukoronida dapat juga dalam bentuk bilirubin terkonjugasi. Proses konjugasi melibatkan enzim glukoroniltransferase, selain dalam bentuk diglukoronida dapat juga dalam bentuk monoglukoronida atau ikatan dengan glukosa, xylosa dan sulfat. terkonjugasi dikeluarkan melalui proses energi kedalam sistem bilier (Lab Kesehatan, 2009).

Selain bilirubin masuk ke dalam usus, bakteri kolon mengubah bilirubin menjadi urobilinogen yaitu beberapa senyawa tidak berwarna yang kemudian mengalami oksidasi menjadi pigmen coklat urobilin.Urobilin diekskresikan dalam feses tetapi sebagian urobilinogen direabsorpsi melalui usus, dan melalui sirkulasi portal diserap oleh hati dan direekskresikan dalam empedu.Karena larut air, urobilinogen juga dapat keluar melalui urin apabila mencapai ginjal (Riswanto, 2009).

\section{METODE PENELITIAN}

Jenis penelitian yang digunakan dalam proposal ilmiah ini adalah jenis penelitian metode Deskriptif Crossectional. Tempat penelitian dilakukan di Laboratorium Rumah Sakit Khusus Paru Medan Sumatera Utara. Waktu penelitian dilaksanakan pada bulan Februari - Juli. Populasi penelitian ini adalah semua pasien yang menderita Tuberkulosis (TB) Paru yang melakukan pengobatan di Laboratorium Rumah Sakit Khusus Paru Medan. Sampel yang digunakan dalam penelitian ini sebanyak 20 sampel penderita TB paru setelah 5 bulan mengkonsumsi Obat Anti Tuberkulosis (OAT). 
Journal of Healthcare Technology and Medicine Vol. 5 No. 2 Oktober 2019

Universitas Ubudiyah Indonesia

e-ISSN : 2615-109X

\section{HASIL DAN PEMBAHASAN}

Dari Penelitian yang telah dilakukan terhadap 20 sampel maka diperoleh hasil sebagai berikut :

Tabel 1. Hasil Pemeriksaan Kadar Bilirubin Total pada 20 sampel

\begin{tabular}{cclcl}
$\begin{array}{c}\text { Kode } \\
\text { Sampel }\end{array}$ & Umur & Jenis Kelamin & $\begin{array}{c}\text { Kadar Bilirubin } \\
\text { Total }(\mathbf{m g} / \mathbf{d l})\end{array}$ & Keterangan \\
BT 01 & 18 & Laki-laki & 0.70 & Normal \\
BT 02 & 22 & Laki-laki & 0.60 & Normal \\
BT 03 & 55 & Perempuan & 0.72 & Normal \\
BT 04 & 56 & Laki-laki & 0.89 & Normal \\
BT 05 & 41 & Perempuan & 0.75 & Normal \\
BT 06 & 51 & Laki-laki & 0.56 & Normal \\
BT 07 & $\mathbf{3 1}$ & Perempuan & $\mathbf{1 . 1 4}$ & Meningkat \\
BT 08 & $\mathbf{2 1}$ & Laki-laki & $\mathbf{1 . 5 1}$ & Meningkat \\
BT 09 & 43 & Laki-laki & 0.65 & Normal \\
BT 10 & 37 & Laki-laki & 0.62 & Normal \\
BT 11 & 55 & Laki-laki & 0.67 & Normal \\
BT 12 & 22 & Laki-laki & 1.00 & Normal \\
BT 13 & 59 & Laki-laki & 0.97 & Normal \\
BT 14 & 48 & Laki-laki & 0.83 & Normal \\
BT 15 & 35 & Perempuan & 1.00 & Normal \\
BT 16 & 47 & Laki-laki & 0.66 & Normal \\
BT 17 & 71 & Laki-laki & 0.61 & Normal \\
BT 18 & 48 & Laki-laki & 0.68 & Normal \\
BT 19 & 38 & Perempuan & 0.77 & Normal \\
BT 20 & 30 & Perempuan & 0.67 & Normal \\
\hline
\end{tabular}

Dari tabel tersebut maka didapati hasil:

- Kadar bilirubin total yang normal dari 20 sampel yang diperiksa adalah 18 $(90 \%)$.

- Kadar bilirubin total yang meningkat dari 20 sampel yang diperiksa adalah 2 $(10 \%)$

\section{PEMBAHASAN}

Berdasarkan penelitian yang dilakukan terhadap darah penderita tuberculosis paru setelah 5 bulan mengkonsumsi OAT di Rumah Sakit Khusus Paru Medan adalah kadar bilirubin total pada darah penderita TB paru setelah 5 bulan mengkonsumsi OAT, dari 20 sampel ditemukan adanya peningkatan kadar bilirubin total sebanyak 2 orang 
Journal of Healthcare Technology and Medicine Vol. 5 No. 2 Oktober 2019

Universitas Ubudiyah Indonesia

e-ISSN : 2615-109X

(10\%), kadar bilirubin total normal sebanyak 18 orang. Dari hasil penelitian ini ditemukan kadar bilirubin total tertinggi yaitu $1.51 \mathrm{mg} / \mathrm{dl}$.

Ini berbeda dengan penelitian yang dilakukan oleh Liviana G. Pondoh di RSUP Prof. Dr. R. P. Kondou Manado pada bulan Januari 2012 - Desember 2014, dimana dari 32 pasien TB yang diperiksa terdapat 15 (47\%) pasien yang mengalami peningkatan kadar bilirubin total.

Peningkatan kadar bilirubin total ini dapat disebabkan karena :

1. Penderita mengkonsumsi OAT secara terus menerus tanpa disertai dengan pola hidup yang sehat.

2. Terjadinya hemolisis eritrosit pada sampel yang diperiksa.

3. Sebelum dilakukan pengobatan dengan OAT kemungkinan kadar bilirubin total pasien sudah meningkat.

Efek dari pemakaian OAT (Isoniazid, Rifampisin, Streptomisin) dapat menyebabkan gangguan fungsi hati, yang termasuk kedalam fungsi hati salah satunya adalah bilirubin.Bilirubin di metabolisme oleh hati dan dieksresikan kedalam empedu. Metabolisme bilirubin dimulai oleh penghancuran eritrosit setelah usia 120 hari oleh sistem retikuloendotel menjadi heme dan globin. Akumulasi bilirubin berlebihan di kulit, sklera dan membran mukosa dapat menyebabkan warna kuning yang disebut ikterus. Ikterus atau Hiperbilirubinemia adalah peningkatan kadar bilirubin yang melebihi batas normal (E.N Kosasih dan E.S Kosasih, 2013).

\section{KESIMPULAN}

Berdasarkan penelitian yang telah dilakukan yang berjudul "Analisa Kadar Bilirubin Total Pada Penderita Tuberculosis (TB) Paru Setelah 5 bulan Mengkonsumsi Obat Anti Tuberkulosis (OAT) di Rumah Sakit Khusus Paru Medan Tahun 2018".Setelah dilakukan pemeriksaan terhadap 20 sampel maka didapati hasil sebagai berikut: normal 18 orang (90\%), meningkat 2 orang (10\%). Penyebab terjadinya kenaikan kadar bilirubin total dapat disebabkan karena penderita mengkonsumsi OAT secara terus menerus tanpa disertai dengan pola hidup sehat, terjadinya hemolisis eritrosit pada sampel yang diperiksa, dan sebelum pasien mengkonsumsi OAT kemungkinan kadar bilirubin total pasien sudah meningkat. 
Journal of Healthcare Technology and Medicine Vol. 5 No. 2 Oktober 2019

Universitas Ubudiyah Indonesia

e-ISSN : 2615-109X

\section{SARAN}

Selama mengkonsumsi OAT disarankan untuk menerapkan pola hidup sehat. Disarankan agar melakukan pemeriksaan darah rutin terlebih dahulu. Selama melakukan pemeriksaan di sarankan serum diperiksa dengan benar dan teliti guna meningkatkan mutu hasil pemeriksaan Laboratorium. Untuk petugas Laboratorium disarankan memakai alat pelindung diri (APD) agar tidak terinfeksi. Disarankan kepada peneliti berikutnya agar melakukan pemeriksaan terhadap parameter faal hati lainnya seperti SGOT, SGPT, gamma GT, alkali fosfatase, cholinesterase dan protein total.

\section{DAFTAR PUSTAKA}

Bakti, Fajar. 2016. Hematologi Praktikum Analis Kesehatan. Jakarta: EGC

E.N, Kosasih \& E.S Kosasih.2013. Tafsiran Hasil Pemeriksaan Laboratorium Klinik. Tangerang: Karisma Publishing Group

Faisalado \& Triwibowo. 2013. Trend Disease Trend Penyakit Saat Ini. Jakarta: Trans Info Media

Rab, Tabrani. 2013. Penyakit Paru. Jakarta: CV Trans Info Media

Rian, Samsu. 2010. Tesis Pengaruh Efek Samping OAT Terhadap Kejadia Default Di Rumah Sakit . Jakarta

Riswanto.2009. Laboratorium Kesehatan Bilirubin Serum. http://labkesehatan.blogspot.com/2009/12/bilirubin serum.html?m=1. Diakses pada 25 Mei 2018. 